\title{
The Efficiency of Health Systems in Response to the COVID-19 Pandemic: Evidence from the EU Countries
}

\section{Wydajność systemów opieki zdrowotnej w odpowiedzi na pandemię COVID-19: przykład krajów należących do UE}

\section{Tamara Rađenović*, Vladimir Radivojevićc**, Bojan Krstić ${ }^{* * *}$, Tanja Stanišićc ${ }^{* \star *}$, Snežana Živković ${ }^{\star * \star * *}$}

\author{
*University of Niš, Faculty of Occupational Safety, Carnojevića st., 10a, 18000 Niš, Serbia, \\ E-mail (Corresponding Author): tamara.radjenovic@znrfak.ni.ac.rs, \\ ORCID: 0000-0003-1632-7772 \\ **University of Priština in Kosovska Mitrovica, Faculty of Economics, Kolašinska st., 156, \\ 38220 Kosovska Mitrovica, Serbia, ORCID: 0000-0002-3928-0623 \\ ***University of Niš, Faculty of Economics, Trg Kralja Aleksandra Ujedinitelja, 11, \\ 18000 Niš, Serbia, ORCID: 0000-0003-4597-6819 \\ ****University of Kragujevac, Faculty of Hotel Management and Tourism in Vrnjačka \\ Banja, Vojvođanska st., 36210 Vrnjačka Banja, Serbia, ORCID: 0000-0001-5809-794X \\ *****University of Niš, Faculty of Occupational Safety, Čarnojevića st., 10a, 18000 Niš, \\ Serbia, ORCID: 0000-0002-7931-9334
}

\begin{abstract}
The COVID-19 pandemic has revealed the insufficient capacities and capabilities of countries around the world to deal with global infectious diseases and stressed the need to improve the international health security framework. An efficient and comprehensive health system that is able to cope with public health emergencies is an essential prerequisite for strengthening health security. The paper analyzes the efficiency of health systems in the European Union (EU) countries and their responsiveness to the COVID-19 pandemic. The research covers 27 EU countries and it is based on the secondary data contained in the 2019 Global Health Security Index Report. The aim of the paper is to identify key determinants for improving the efficiency of health systems in the EU, as well as to examine the interdependence between health expenditures and the efficiency of health system in this sample of countries. The research is conducted through descriptive statistics and correlation and regression analysis. The conclusions can be useful for the EU policy makers in formulating a strategy to improve the efficiency of Member States' health systems and preparedness for possible new pandemics.
\end{abstract}

Key words: efficiency, health system, health security, health expenditures, EU countries, COVID-19

\section{Streszczenie}

Pandemia COVID-19 ujawniła niewystarczające zasoby krajów na całym świecie do radzenia sobie z globalnymi chorobami zakaźnymi i podkreśliła potrzebę poprawy międzynarodowych ram bezpieczeństwa zdrowotnego. Wydajny i kompleksowy system opieki zdrowotnej, który jest w stanie poradzić sobie z sytuacjami kryzysowymi dotyczącymi zdrowia publicznego, jest niezbędnym warunkiem wzmocnienia bezpieczeństwa zdrowotnego. Artykuł analizuje efektywność systemów opieki zdrowotnej w krajach Unii Europejskiej (UE) i ich reakcję na pandemię COVID-19. Badanie obejmuje 27 krajów UE i opiera się na danych wtórnych zawartych w raporcie Global Health Security Index 2019. Celem artykułu jest identyfikacja kluczowych determinant poprawy efektywności systemów ochrony zdrowia w UE oraz zbadanie współzależności między wydatkami na zdrowie a efektywnością systemu ochrony zdrowia w tej grupie krajów. Badania uwzględniają statystyki opisowe oraz analizę korelacji i regresji. Wnioski mogą być przydatne dla decydentów UE przy formułowaniu strategii poprawy efektywności systemów opieki zdrowotnej państw członkowskich oraz gotowości na ewentualne nowe pandemie.

Słowa kluczowe: wydajność, system zdrowotny, bezpieczeństwo zdrowotne, wydatki na zdrowie, kraje UE, COVID-19 


\section{Introduction}

Human health and ways to protect and improve it can be interpreted as the basic goals of humanity and as central issues in the research of theorists and practitioners in various fields. According to the World Health Organization, health is a state of complete physical, mental, and social well-being and not merely the absence of disease or infirmity. There is no doubt that humanity has significantly improved the quality of health in previous centuries. Today, most of the world's population has access to the water, sanitation, and hygiene. Numerous countries have built complex health care systems with the modern procedures and equipment that enable a healthy lifestyle of people. Global knowledge and experience in the field of health is expanding constantly and today is greater than ever before. However, health improvement is extremely unequal in a global perspective.

For example, a child born in Hong Kong can expect to live more than 84 years, while life expectancy of his peer in Ukraine is 72 years, and less than 54 years if child is born in Central African Republic (United Nations, 2020). Such huge inequalities in life expectancy across countries cannot be clarified through biology. Differences in health conditions between (and within) countries are a consequence of the economic and social policies that determine the environment in which people are born, grow, live, and work (Council of Europe, n.d.). Namely, the life expectancy and health care quality of population largely depend on the level of economic and social development.

The COVID-19 pandemic exposed the differences in the efficiency of health systems around the world, but also revealed the lack of global readiness to face public health emergencies. This pandemic has forced national economies across the globe to analyze their capacities and capabilities to prevent, detect, and quickly respond to the occurrence of infectious diseases and other acute forms of endangering the public health. Health systems that are able to respond effectively to such health threats have a significant advantage in reducing their negative health, social, and economic consequences.

The paper evaluates the efficiency of health systems in the 27 European Union (EU) countries in terms of prevention, detection, and rapid response to the pandemics on the example of COVID-19. The goal is to determine key factors in improving the efficiency of health systems in EU countries and, thus, enhance the health security of their citizens for possible new pandemics. Also, the paper considers the impact of health expenditures in EU countries on the efficiency of their health systems. The research findings can serve as guidelines for health policy makers in all EU countries.

The paper contains five separate segments. The first segment deals with the theoretical background and review of the literature on health security and effi- ciency of the health system. The analysis of determinants of health system efficiency in the EU countries is presented in the second segment of the paper. Research methodology and hypotheses are defined in the third segment. The empirical results of the research are presented and discussed in the fourth segment. The last segment provides the concluding remarks and recommendations for improving the efficiency of health systems in the observed countries.

\section{Theoretical background and literature review}

Despite the fact that statistics show that the rate of infectious diseases in the EU countries has been declining in recent decades, sudden health shocks in the previous period have confirmed that threats to public health in the EU and the rest of the world exist permanently. Severe acute respiratory syndrome (SARS) in 2002, Swine flu pandemic (H1N1) in 2009, Escherichia Coli outbreak in Germany in 2011, Ebola virus disease in 2014, Zika in 2016, and, finally, COVID-19 in 2019 show that global threats through new infectious diseases can arise at any time and in any place.

Theoretical and empirical studies in the field of health system efficiency and health security of national economies demonstrate that this topic has attracted special attention of researchers at a time when the world was facing global challenges to public health. The occurrence of these studies in the last two decades can be attributed to efforts to explore and learn lessons from the consequences of the aforementioned infectious diseases. However, due to its global population coverage and duration, but also extremely pessimistic predictions about its social and economic consequences, it seems that the COVID-19 pandemic has caused the greatest attention of the professional and scientific public in recent history.

There is a broad consensus between researchers that the COVID-19 pandemic amplifies several problems of national economies and societies, which were serious and obvious even before (Anand et al., 2020; Ferrannini et al., 2021). A large number of studies published in the previous period (Jones et al., 2008; Morens et al., 2004; Morse et al., 2012; Webster, 1997) pointed to the catastrophic consequences that a possible global pandemic would have on international supply chains and cross-border economic cooperation, but also on individuals, welfare, and polices. Apparently, the COVID-19 pandemic threatens to exceed such predictions (Acemoglu et al., 2020; Albanesi \& Kim, 2021; Alon et al., 2020; Glover et al., 2020; Boyce et al., 2021; Kandel et al., 2020; Kaplan et al., 2021; Stojanović-Jovanović et al., 2020). By the end of June 2021, more than 181 million confirmed cases of COVID-19 infection and more than 3.93 million deaths from the disease have been reported worldwide, while social and economic trends have completely shifted from their usual 
Table 1. Health expenditure per capita in EU countries, PPP (current international \$), 2013-2018, source: World Bank (2021)

\begin{tabular}{|c|c|c|c|c|c|c|c|}
\hline \multirow{2}{*}{ Country } & \multicolumn{6}{|c|}{ Year } & \multirow{2}{*}{ Average } \\
\hline & 2013 & 2014 & 2015 & 2016 & 2017 & 2018 & \\
\hline Austria & 4,945 & 5,083 & 5,206 & 5,476 & 5,674 & 5,879 & 5,377 \\
\hline Belgium & 4,621 & 4,703 & 4,835 & 5,007 & 5,289 & 5,405 & 4,977 \\
\hline Bulgaria & 1,186 & 1,349 & 1,355 & 1,468 & 1,575 & 1,634 & 1,428 \\
\hline Croatia & 1,420 & 1,475 & 1,554 & 1,668 & 1,773 & 1,876 & 1,628 \\
\hline Cyprus & 2,100 & 2,078 & 2,199 & 2,359 & 2,498 & 2,625 & 2,310 \\
\hline Czech Republic & 2,380 & 2,472 & 2,442 & 2,522 & 2,753 & 3,041 & 2,602 \\
\hline Denmark & 4,762 & 4,887 & 5,038 & 5,291 & 5,589 & 5,794 & 5,227 \\
\hline Estonia & 1,650 & 1,770 & 1,866 & 2,009 & 2,230 & 2,428 & 1,992 \\
\hline Finland & 4,069 & 4,084 & 4,099 & 4,212 & 4,340 & 4,457 & 4,210 \\
\hline France & 4,547 & 4,659 & 4,692 & 4,943 & 5,110 & 5,250 & 4,867 \\
\hline Germany & 4,953 & 5,193 & 5,355 & 5,574 & 5,931 & 6,098 & 5,517 \\
\hline Greece & 2,163 & 2,100 & 2,149 & 2,239 & 2,274 & 2,340 & 2,211 \\
\hline Hungary & 1,773 & 1,808 & 1,835 & 1,949 & 2,004 & 2,115 & 1,914 \\
\hline Ireland & 4,949 & 4,962 & 5,079 & 5,365 & 5,617 & 5,897 & 5,311 \\
\hline Italy & 3,216 & 3,210 & 3,266 & 3,417 & 3,572 & 3,624 & 3,384 \\
\hline Latvia & 1,218 & 1,296 & 1,406 & 1,631 & 1,704 & 1,896 & 1,525 \\
\hline Lithuania & 1,629 & 1,739 & 1,862 & 1,999 & 2,143 & 2,313 & 1,947 \\
\hline Luxembourg & 5,346 & 5,574 & 5,547 & 5,675 & 5,870 & 6,048 & 5,677 \\
\hline Malta & 2,767 & 3,157 & 3,374 & 3,541 & 3,891 & 3,897 & 3,438 \\
\hline Netherlands & 5,219 & 5,214 & 5,205 & 5,280 & 5,499 & 5,635 & 5,342 \\
\hline Poland & 1,575 & 1,627 & 1,717 & 1,851 & 1,979 & 2,015 & 1,794 \\
\hline Portugal & 2,529 & 2,587 & 2,659 & 2,972 & 3,084 & 3,242 & 2,846 \\
\hline Romania & 1,026 & 1,035 & 1,066 & 1,188 & 1,368 & 1,576 & 1,210 \\
\hline Slovak Republic & 2,101 & 1,999 & 2,034 & 2,110 & 2,094 & 2,180 & 2,086 \\
\hline Slovenia & 2,621 & 2,626 & 2,689 & 2,816 & 2,961 & 3,158 & 2,812 \\
\hline Spain & 2,934 & 3,045 & 3,186 & 3,276 & 3,482 & 3,576 & 3,250 \\
\hline Sweden & 5,073 & 5,193 & 5,331 & 5,396 & 5,636 & 5,828 & 5,410 \\
\hline
\end{tabular}

flows. Also, according to Eurostat data on annual growth for 2020 (2021), GDP fell by $6.5 \%$ in the euro area and $6.1 \%$ in the EU.

Theoretical and empirical surveys that seek to explain the impact of the pandemic on economic and social developments in the world are constantly growing. Some of these studies explore the balance between minimizing adverse effects on human health and mitigating economic disruption in the global market (Alvarez et al., 2020; Jones et al., 2020). Others focus their research on measuring the impact of the pandemic on employment (Green \& Loualiche, 2021), small and medium-sized enterprises (Bartik et al., 2020), financial markets (Ashraf, 2020; Mensi et al., 2020; Zhang et al., 2020), stock markets (Machmuddah, 2020; Ozkan, 2021), and public spending (Baker et al., 2020a; Baker et al., 2020b; Eichenbaum, 2020). The general conclusion of all mentioned studies is that the current health crisis will leave a deep mark in economic and social welfare on a global level, and that increasing the efficiency of health systems, which is reflected in the degree of resistance to such health shocks in the future, will be a necessary precondition for recovery and functioning in an international environment. The concept of health system efficiency is quite controversial in practice and is very difficult to apply in a comparative analysis across countries (Cylus et al., 2017b; Reinhardt et al., 2002). There are not many attempts in the relevant literature to formulate unique comparative measures (indicators) to be used in evaluating the effectiveness of national health systems. Furthermore, Cylus et al. (2017a) consider that all available studies have visible limitations, including a lack of a clear conceptual framework, limited data availability, and difficulties in selecting reliable and appropriate empirical techniques. Specifically, there is no consensus in the scientific community on the theoretical or statistical criteria that should be used to conduct such empirical analyses (Streetand \& Hakkinen, 2009). Nonetheless, the health system efficiency is important as it seeks to capture the extent to which the inputs to the health system, in the form of expenditures and other resources, are used to secure valued health system goals (Cylus et al., 2017b: 7). It is the growing concern for policy makers and managers especially in the times of crises.

The analysis of determinants of health system efficiency in the EU countries

\section{A) The analysis of financial support to the health system in the EU countries}

Financial support to the health system is an important prerequisite for its building and development. The level of health expenditures in a national economy depends on numerous demographic, social, and economic factors, as well as the financial concept and organizational structure of the health sys- 
tem itself. This clearly suggests that there are significant disparities in the level of health expenditures among countries in the EU. OECD and EU (2020) found that there is a strong correlation between national income and health expenditures, so high-income EU countries are typically those that spent the most on health. The same conclusion emerges from this paper through an analysis of health expenditures per capita in EU countries in the period 2014-2018 (Table 1).

According to the World Bank (2021) data, the average health expenditures per capita (adjusted for differences in countries' purchasing powers) of EU countries in the period 2013-2018 amounted to \$ 3,344 . On average across EU member states, health expenditures have continuously increased from \$ 3,066 in 2013 to $\$ 3,697$ in 2018, which is an average growth of around $3.7 \%$ per year between 2013 and 2018. It is indicative that all EU countries achieved a positive growth of health expenditures in the observed period. However, Table 1 shows significant differences in the level of health expenditures in EU countries.

With average spending at $\$ 5,677$ per person, Luxembourg was the largest spending country in the EU, followed by Germany $(\$ 5,517)$, Sweden $(\$ 5,410)$, Austria (\$ 5,377), Netherlands (\$ 5,342), Ireland (\$ $5,311)$, and Denmark $(\$ 5,227)$. Spending levels in the seven mentioned EU countries were at least $50 \%$ above the EU average $(\$ 3,344)$. At the opposite end of the scale, Romania $(\$ 1,210)$, Bulgaria $(\$ 1,428)$, Latvia $(\$ 1,525)$, and Croatia $(\$ 1,628)$ were the lowest spenders in the EU region, with less than $50 \%$ of health expenditures compared to the EU average. Comparing the average annual investment in the health system of Luxembourg (as the leading EU country in terms of health expenditures) and Romania (as the country with the lowest health expenditures in the EU) shows a huge difference in financial support to health systems between EU member states. Namely, Luxembourg invested 4.7 times more in its health system in the observed period than Romania. Such large disparities in financial support to the health system over time necessarily lead to significant differences in health security conditions between countries.

\section{B) The analysis of EU health systems responses to COVID-19}

The COVID-19 pandemic is an unprecedented health, social, and economic shock that has surprised the world and the global economy. Countries across the EU region applied numerous and comprehensive responses to the virus, such as closing borders and total lockdown, but also providing masks, ventilators, and vaccines. However, coronavirus mortality and morbidity rates exist within the context of a national healthcare system and a population (World Bank, 2020). Table 2 presents data of John Hopkins
University (2021) on confirmed cases and deaths due to the COVID-19 virus in EU countries.

Table 2. Confirmed cases and deaths due to the COVID19 in the EU countries, source: John Hopkins University 2021

\begin{tabular}{|l|c|c|c|}
\hline Country & Cofirmed & Deaths & $\begin{array}{c}\text { Deaths/ } \\
\mathbf{1 0 0 , 0 0 0}\end{array}$ \\
\hline Austria & 649,576 & 10,680 & 120.31 \\
\hline Belgium & $1,079,415$ & 25,136 & 218.88 \\
\hline Bulgaria & 421,032 & 17,990 & 257.89 \\
\hline Croatia & 359,173 & 8,174 & 200.96 \\
\hline Cyprus & 73,643 & 374 & 31.20 \\
\hline Czech Republic & $1,666,025$ & 30,280 & 283.79 \\
\hline Denmark & 292,467 & 2,531 & 43.50 \\
\hline Estonia & 130,806 & 1,268 & 95.58 \\
\hline Finland & 94,334 & 967 & 17.52 \\
\hline France & $5,819,088$ & 110,900 & 165.37 \\
\hline Germany & $3,730,126$ & 90,400 & 108.74 \\
\hline Greece & 418,342 & 12,542 & 117.04 \\
\hline Hungary & 807,428 & 29,950 & 306.55 \\
\hline Ireland & 269,037 & 4,979 & 100.76 \\
\hline Italy & $4,252,976$ & 127,270 & 211.07 \\
\hline Latvia & 136,810 & 2,496 & 130.49 \\
\hline Lithuania & 278,379 & 4,366 & 156.66 \\
\hline Luxembourg & 70,516 & 818 & 131.96 \\
\hline Malta & 30,589 & 420 & 83.56 \\
\hline Netherlands & $1,706,611$ & 18,007 & 103.89 \\
\hline Poland & $2,878,767$ & 74,828 & 197.07 \\
\hline Portugal & 865,050 & 17,065 & 166.17 \\
\hline Romania & $1,080,256$ & 32,326 & 167.00 \\
\hline Slovak Republic & 391,248 & 12,478 & 228.78 \\
\hline Slovenia & 256,982 & 4,412 & 211.31 \\
\hline Spain & $3,757,442$ & 80,652 & 171.32 \\
\hline Sweden & $1,084,636$ & 14,574 & 141.70 \\
\hline
\end{tabular}

According to John Hopkins University (2021) data presented in Table 2, a total of 32,600,754 confirmed cases of COVID-19 virus and 735,883 deaths from this infectious disease were registered in the EU region by June 22, 2021. Nevertheless, key parameters for evaluating the health system's readiness to identify, prevent, and respond to public health threats such as the COVID-19 pandemic lie in the mortality rate, i.e. in the number of deaths per 100,000 population.

With 306.55 deaths per 100,000 population, Hungary has the highest mortality in this population sample in the EU region, followed by Czech Republic (283.79 deaths), Bulgaria (257.89 deaths), Slovak Republic (228.78 deaths), Belgium (218.88 deaths), Slovenia (211.31 deaths), and Italy (211.07 deaths). Out of 180 countries in the world for which the above statistics are monitored, Hungary took the 2nd place, Czech Republic 4th place, Bulgaria 8th place, Slovak Republic 11th place, Belgium 12th, Slovenia 13th, and Italy 14th place in terms of deaths per 100,000 population. Therefore, even seven EU member states are in the top 14 countries in the world according to the number of deaths per 100,000 population. These data clearly confirm that the COVID-19 pandemic has exposed the insufficient 
preparation and efficiency of some health systems in EU region to deal with major public health emergencies.

\section{Methodology and hypotheses}

The efficiency of health systems in the EU countries is observed through the prism of prevention, detection, and rapid response to pandemics and other forms of endangering public health. Capacities and capabilities for responding to pandemics are analyzed based on data presented in the Global Health Security Index Report, published by the Nuclear Threat Initiative and the Johns Hopkins Center for Health Security (2019). The Global Health Security Index is a comprehensive measure that shows the level of national preparedness to prevent and mitigate epidemics and pandemics (Ravi et al., 2020). The methodological framework for the Global Health Security Index calculation consists of 140 questions, grouped into 85 sub-indicators, 34 indicators and the following 6 categories: (1) Prevention; 2) Detection and reporting; (3) Rapid response; (4) Health system; (5) Compliance with international norms; and (6) Risk environment. Each of the above categories (as well as indicators, sub-indicators and questions) is scored on a scale from 0 to 100 , where 0 represents the lowest and 100 the highest score in terms of national health security. Global Health Security Index Report 2019 covers 195 countries, including 27 EU national economies.

Giving an answer to the defined aim implies testing the following hypotheses:

H1: Investments in health system have positive influence on the GHS Index.

H1.1. Health expenditure as \% of GDP has positive impact on GHS Index.

H1.2. Health expenditure per capita has positive impact on GHS Index.

H2: Investments in health system have positive influence on the category Prevention of GHS index.

H2.1. Health expenditure as \% of GDP has positive impact on the category Prevention of GHS index.

H2.2. Health expenditure per capita has positive impact on the category Prevention of GHS index.

H3: Investments in health system have positive influence on the category Health system of GHS Index.

H3.1. Health expenditure as \% of GDP has positive impact on the category Health system of GHS Index.

H3.2. Health expenditure per capita has positive impact on the category Health system of GHS Index.

H4: The level of detection of health system increases the number of confirmed COVID-19 cases.

H5: The number of deaths from COVID-19 is influenced by the level of rapid response of health system and the number of confirmed COVID-19 cases.
For testing defined hypothesis regression and correlation analysis are performed. The list of used variables is presented in Table 3 .

Table 3. List of used variables, source: authors' own work

\begin{tabular}{|l|c|c|}
\hline Variable & $\begin{array}{c}\text { Variable } \\
\text { Type }\end{array}$ & Model \\
\hline $\begin{array}{l}\text { Global Health Security } \\
\text { Index (GHSI) }\end{array}$ & Dependent & Model 1-2 \\
\hline Prevention (PREV) & Dependent & Model 3-4 \\
\hline Detection (DET) & Predictor & Model 7 \\
\hline Rapid Response (RESP) & Predictor & Model 8 \\
\hline Health System (HS) & Dependent & Model 5-6 \\
\hline $\begin{array}{l}\text { Current health expendi- } \\
\text { ture (\% of GDP) } \\
\text { (CHEgdp) }\end{array}$ & Predictor & Model 1-6 \\
\hline $\begin{array}{l}\text { Current health expendi- } \\
\text { ture per capita, PPP } \\
\text { (current international \$) } \\
\text { (CHEpc) }\end{array}$ & Predictor & Model 1-6 \\
\hline $\begin{array}{l}\text { Confirmed cases } \\
\text { (CONF) }\end{array}$ & Dependent & Model 7 \\
\cline { 2 - 3 } $\begin{array}{l}\text { Deaths per 100,000 } \\
\text { population (D100) }\end{array}$ & Predictor & Model 8 \\
\hline
\end{tabular}

\section{Empirical analysis and discussion}

Data used in this study are from the Global Health Security Index (GHSI, PREVENT, DETECT, HS from 2019 Report), the Johns Hopkins University Coronavirus Resource Center (CONFIRMED, DEATHS from June 22, 2021) and the World Bank Development Indicators database (CHEgdp, CHEpc for the period 2013-2018). Our sample includes the 27 EU countries.

The descriptive statistics are presented in Table 4. The average current health expenditure as percent of GDP in the analyzed countries is 8.25 percent, while the least average value of 5.14 percent is recorded in Romania, and the highest average value of 11.44 percent is recorded in France. The average current health expenditure per capita in the analyzed countries is \$3,344.13 (PPP, current international \$), while the least average value of $\$ 1,210.04$ in 2013 2018 is recorded in Romania, and the highest value of $\$ 5,676.73$ is recorded in Luxembourg. The average number of confirmed COVID-19 cases is $1,207,435$ and the minimum number of cases 30,589 is recorded on Malta, while the maximum is $5,849,088$ in France. The average number of deaths per 100,000 population is 154.41 and the minimum number of deaths 17.52 is recorded in Finland, while the maximum is 306.55 in Hungary. As regards the GHSI the average value in the EU countries is 57.63, the minimum of 37.30 is recorded on Malta, and the maximum of 75.6 in Netherlands.

Correlation results are presented in Table 5. Results show that correlation between GHSI and current health expenditure as percent of GDP is positive, strong, and statistically significant (0.6455). Also, the correlation between GHSI and current health expenditure per capita is positive, moderate, and statis- 
Table 4. Descriptive Statistics, source: Authors' calculations

\begin{tabular}{|c|c|c|c|c|}
\hline Variable & Minimum & Maximum & Mean & Std. Dev. \\
\hline GHSI & 37.3 & 75.6 & 57.6259 & 9.8041 \\
\hline PREV & 31.0 & 81.1 & 55.7852 & 12.2367 \\
\hline DET & 32.9 & 97.3 & 67.3148 & 17.1563 \\
\hline RES & 21.7 & 79.1 & 49.0593 & 15.6462 \\
\hline HS & 21.9 & 70.2 & 45.4259 & 12.2922 \\
\hline CHEgdp & 5.14 & 11.44 & 8.2493 & 1.8582 \\
\hline CHEpc & $1,210.04$ & $5,676.73$ & $3,344.13$ & $1,562.17$ \\
\hline CONF & 30,589 & $5,849,088$ & $1,207,435$ & $1,530,668$ \\
\hline D & 17.52 & 306.55 & 154.41 & 72.71 \\
\hline
\end{tabular}

Table 5. Correlations, source: Authors' calculations

\begin{tabular}{|c|c|c|c|c|c|c|c|c|c|}
\hline & GHSI & PREV & DET & RESP & HS & CHEgdp & CHEpc & CONF & D \\
\hline GHSI & 1 & & & & & & & & \\
\hline PREV & $0.8763^{*}$ & 1 & & & & & & & \\
\hline DET & $0.7699^{*}$ & $0.5914^{*}$ & 1 & & & & & & \\
\hline RESP & $0.8514^{*}$ & $0.7015^{*}$ & $0.5468^{*}$ & 1 & & & & & \\
\hline HS & $0.8431^{*}$ & $0.7131^{*}$ & $0.4831^{*}$ & $0.6551^{*}$ & 1 & & & & \\
\hline CHEgdp & $0.6455^{*}$ & $0.6774^{*}$ & 0.3565 & $0.4631^{* *}$ & $0.5957^{*}$ & 1 & & & \\
\hline CHEpc & $0.4958^{*}$ & $0.5001^{*}$ & 0.2524 & 0.2917 & $0.4674^{*}$ & $0.7214^{*}$ & 1 & & \\
\hline CONF & 0.3384 & 0.2339 & 0.2654 & 0.2876 & 0.3301 & $0.4373^{* *}$ & 0.2226 & 1 & \\
\hline D & -0.1961 & -0.1854 & -0.1916 & -0.1897 & -0.0626 & -0.2246 & $-0.4029 * *$ & 0.2197 & 1 \\
\hline
\end{tabular}

Note: * Correlation is significant at the 0.01 level (2-tailed), ** Correlation is significant at the 0.05 level (2-tailed)

Table 6. Regression results

\begin{tabular}{|c|c|c|c|c|c|}
\hline Model 1 & Constant & CHEgdp & \multicolumn{2}{|c|}{$\mathbf{R}^{2}$} & Adjusted $R^{2}$ \\
\hline \multirow[b]{2}{*}{$\ln$ GHSI } & \multirow{2}{*}{$\begin{array}{l}3.5590 \\
{[27.98]} \\
(0.000)\end{array}$} & \multirow{2}{*}{$\begin{array}{c}0.00582 \\
{[3.87]} \\
(0.001)\end{array}$} & \multicolumn{2}{|c|}{0.3743} & 0.3493 \\
\hline & & & \multicolumn{2}{|c|}{ F statistics } & $\begin{array}{c}14.96 \\
(0.0000)\end{array}$ \\
\hline Model 2 & Constant & In CHEpc & \multicolumn{2}{|c|}{$\mathbf{R}^{2}$} & Adjusted R ${ }^{2}$ \\
\hline \multirow[b]{2}{*}{ ln GHSI } & \multirow{2}{*}{$\begin{array}{c}2.7221 \\
{[5.38]} \\
(0.000)\end{array}$} & \multirow{2}{*}{$\begin{array}{c}0.1646 \\
{[2.61]} \\
(0.015)\end{array}$} & \multicolumn{2}{|c|}{0.2142} & 0.1827 \\
\hline & & & \multicolumn{2}{|c|}{ F statistics } & $\begin{array}{c}6.81 \\
(0.0151)\end{array}$ \\
\hline Model 3 & Constant & CHEgdp & \multicolumn{2}{|c|}{$\mathbf{R}^{2}$} & Adjusted $\mathbf{R}^{2}$ \\
\hline \multirow[b]{2}{*}{ ln PREV } & \multirow{2}{*}{$\begin{array}{l}3.3419 \\
{[20.74]} \\
(0.000)\end{array}$} & \multirow{2}{*}{$\begin{array}{c}0.0794 \\
{[4.16]} \\
(0.000)\end{array}$} & \multicolumn{2}{|c|}{0.4095} & 0.3859 \\
\hline & & & \multicolumn{2}{|c|}{ F statistics } & $\begin{array}{c}17.34 \\
(0.0000)\end{array}$ \\
\hline Model 4 & Constant & In CHEpc & \multicolumn{2}{|c|}{$\mathbf{R}^{2}$} & Adjusted $\mathbf{R}^{2}$ \\
\hline \multirow[b]{2}{*}{ In PREV } & \multirow{2}{*}{$\begin{array}{l}2.4709 \\
{[3.65]} \\
(0.001) \\
\end{array}$} & \multirow{2}{*}{$\begin{array}{l}0.1907 \\
{[2.26]} \\
(0.033) \\
\end{array}$} & \multicolumn{2}{|c|}{0.1691} & 0.1359 \\
\hline & & & \multicolumn{2}{|c|}{ F statistics } & $\begin{array}{c}5.09 \\
(0.0331)\end{array}$ \\
\hline Model 5 & Constant & CHEgdp & \multicolumn{2}{|c|}{$\mathbf{R}^{2}$} & Adjusted $R^{2}$ \\
\hline & 3.0836 & 0.0842 & 0.25 & & 0.2676 \\
\hline $\ln \mathrm{HS}$ & $\begin{array}{l}{[14.05]} \\
(0.000)\end{array}$ & $\begin{array}{c}{[3.24]} \\
(0.003) \\
\end{array}$ & & atistics & $\begin{array}{c}10.50 \\
(0.0034)\end{array}$ \\
\hline Model 6 & Constant & In CHEpc & $\mathbf{R}$ & & Adjusted $\mathbf{R}^{2}$ \\
\hline & 1.8815 & 0.2371 & 0.16 & & 0.1346 \\
\hline $\ln \mathrm{HS}$ & $\begin{array}{c}{[2.22]} \\
(0.035)\end{array}$ & $\begin{array}{c}{[2.25]} \\
(0.034)\end{array}$ & & atistics & $\begin{array}{c}5.04 \\
(0.0338)\end{array}$ \\
\hline Model 7 & Constant & In DET & $\mathbf{R}$ & & Adjusted $\mathbf{R}^{2}$ \\
\hline & 5.4736 & 1.8511 & 0.14 & & 0.1056 \\
\hline $\ln \mathrm{CONF}$ & $\begin{array}{c}{[1.43]} \\
(0.166) \\
\end{array}$ & $\begin{array}{c}{[2.02]} \\
(0.054) \\
\end{array}$ & & atistics & $\begin{array}{c}4.07 \\
(0.0545) \\
\end{array}$ \\
\hline Model 8 & Constant & In RESP & Ln CONF & $\mathbf{R}^{2}$ & Adjusted $\mathbf{R}^{2}$ \\
\hline & 3.7369 & -0.8038 & 0.3205 & 0.4087 & 0.3595 \\
\hline $\ln \mathrm{D}$ & $\begin{array}{c}2.94] \\
(0.007)\end{array}$ & $\begin{array}{l}{[-2.50]} \\
(0.020)\end{array}$ & $\begin{array}{c}{[3.95]} \\
(0.001)\end{array}$ & F st: & $\begin{array}{c}8.30 \\
(0.0018)\end{array}$ \\
\hline
\end{tabular}

Note: $\mathrm{t}$ values are given in [ ], $\mathrm{p}$ values are given in ( ) 
tically significant (0.4958). Additionally, the positive strong statistically significant correlation exists between prevention and current health expenditure either as percent of GDP (0.6774) or per capita (0.5001). The correlation between Health System and current health expenditure as percent of GDP is positive, strong, and statistically significant (0.5957), while between Health System and current health expenditure per capita is positive, moderate, and statistically significant (0.4674). The correlation between current health expenditure as percent of GDP and confirmed cases is positive, moderate, and statistically significant $(0.4373)$, while between current health expenditure per capita and deaths per 100,000 population exists negative, moderate, and statistically significant correlation (-0.4029).

The regression results are presented in Table 6. First two models explain the effects of current health expenditures on GHS index. Model 1 analyses the impact of current health expenditure as percent of GDP (CHEgdp) on GHS index in 27 EU countries and confirms the positive and statistically significant impact as we expected. If the current health expenditure as percent of GDP increases by 1 percent, the GHS index will increase by 0.58 percent. The estimated model explains 37.43 percent change in GHS index and this model is statistically significant as confirmed by the $F$ test $(p<0.01)$. Model 2 explains the effects of current health expenditure per capita (CHEpc) on GHS index and also confirms the positive and statistically significant impact. If the current health expenditure per capita increases by 1 percent, the GHS index will increase by 0.16 percent. The estimated model explains 21.42 percent change in GHS index and this model is statistically significant as confirmed by the $F$ test $(p<0.05)$. The results of these models suggest towards accepting the H1.1. and H1.2. hypotheses, and hence towards overall accepting the $\mathrm{H} 1$ hypothesis.

Following two models explain the effects of current health expenditures on Prevention. Model 3 analyses the impact of current health expenditure as percent of GDP (CHEgdp) on Prevention and confirms the positive and statistically significant impact as we expected. If the current health expenditure as percent of GDP increases by 1 percent, the Prevention will increase by 7.94 percent. The estimated model explains 40.95 percent change in Prevention and this model is statistically significant as confirmed by the $F$ test $(p<0.01)$. Model 4 explains the effects of current health expenditure per capita (CHEpc) on Prevention and also confirms the positive and statistically significant impact. If the current health expenditure per capita increases by 1 percent, the Prevention will increase by 0.19 percent. The estimated model explains 16.91 percent change in Prevention and this model is statistically significant as confirmed by the $\mathrm{F}$ test $(\mathrm{p}<0.05)$. Therefore, we can accept the hypotheses H2.1. and H2.2., and overall, the $\mathrm{H} 2$ hypothesis.
Next two models explain the effects of current health expenditures on Health System. Model 5 analyses the impact of current health expenditure as percent of GDP (CHEgdp) on Health System and confirms the positive and statistically significant impact as we expected. If the current health expenditure as percent of GDP increases by 1 percent, the Health System will increase by 8.42 percent. The estimated model explains 29.58 percent change in Health System and this model is statistically significant as confirmed by the $F$ test $(p<0.01)$. Model 4 explains the effects of current health expenditure per capita (CHEpc) on Health System and also confirms the positive and statistically significant impact. If the current health expenditure per capita increases by 1 percent, the Health System will increase by 0.23 percent. The estimated model explains 16.79 percent change in Health System and this model is statistically significant as confirmed by the F test $(\mathrm{p}<0.05)$. These results point towards acceptance of hypotheses H3.1. and H3.2. and hence, the H3 is confirmed as well. Model 7 analyses the impact of Detection on Confirmed cases of COVID-19. The results confirm that 1 percent increase in Detection leads to the increase in Confirmed cases by $1.85 \%$. The estimated model explains 14 percent change in Confirmed cases and it is statistically significant as confirmed by the $\mathrm{F}$ test $(p<0.10)$. Finally, Model 8 investigates the effects of Rapid Response and Confirmed cases on the Deaths per 100,000 population. The results show that 1 percent increase in Rapid Response leads to the 0.80 percent decrease in the Deaths per 100,000 population, while the 1 percent increase in Confirmed cases results in the increase of the Deaths per 100,000 population by 0.32 percent. The estimated model explains 40.89 percent change in Deaths per 100,000 population and this model is statistically significant as confirmed by the $F$ test $(p<0.01)$. These results enable us to verify the hypotheses H4 and H5.

The results obtained in this study undoubtedly confirmed that investments in health systems are important in determining their overall efficiency and responsiveness to the pandemics. Higher investments in health systems improve the capacities and capabilities of the health systems to prevent, detect and rapidly response to the pandemics, thus strengthening the heath security of all citizens and reducing the number of deaths. These results correspond to the conclusions drawn by Dyakova et al. (2017: $\mathrm{x}$ ) that investments for health and well-being are priority for strengthening public health systems, capacities and services to ensure national and global health security. Furthermore, the OECD (2020) study stresses the need to pursue the health system strengthening in parallel with the health security efforts for prevention, detection, and rapid response to pandemics in order to develop resilient health systems. Health systems resilience implies the capacities of the health institutions and stuff to effectively respond and manage crisis, without jeopardizing their core operations 
(Lal et al., 2021). The COVID-19 pandemic more than ever raised the question of aligning all health system capacities and capabilities towards preventing pandemics, while continuing principal health services at satisfactory level.

\section{Conclusion}

Global COVID-19 pandemic has raised the question of the efficiency of health systems around the world and their preparedness to deal with unforeseen events and circumstances. These issues have become even more important for policy makers and managers due to the financial concerns regarding the continuing economic sustainability and resilience of health systems. The countries' responses to COVID19 have been diverse, mainly dependent on the resilience of their health systems, and are still contextual and ongoing issues. Considering all this, our intention was to contribute to the existing discussion and give insights regarding efficiency of health systems. We investigated the efficiency of the health systems in the EU countries, as well as their responsiveness to the COVID-19 pandemic.

The efficiency of the health system is assessed based on the Global Health Security Index, as the overall measure, and its main categories - prevention, detection, rapid response, and health system, showing the countries' readiness for prevention and mitigation of pandemics and other health threats. The key determinants impacting the overall efficiency of the health system, as well as prevention and health system capacity are investments in health system. The correlation analysis results determined positive, statistically significant correlation between health expenditures, either as percent of GDP or per capita, and GHS index, Prevention and Health System. The results of the regression analysis revealed positive, statistically significant impact of health expenditures on these efficiency measures. Hence, the first three hypotheses of this study were confirmed.

Further, the results of the study determined the positive impact of detection capacity of health system on the confirmed cases of COVID-19 pandemics, as well as the impact of rapid response capability of the health system on reducing the number of deaths per 100,000 population. Thus, the last two hypotheses were also verified.

As the level of health expenditures in an economy depends on diverse demographic, social, economic, and organizational factors, there are significant disparities among countries regarding the level of health expenditure. The analysis revealed that, although the health expenditures exhibit positive trend at an average rate of $3.7 \%$ per year for the period 2013-2018, the high-income EU countries invest more in their health systems, than the low-income EU countries. The comparison between the leading EU country in terms of health expenditures (Luxembourg) and the country with the lowest health ex- penditures (Romania) showed that investments in health system in Luxembourg are 4.7 times bigger than in Romania.

Based on all the above mention, it is evident that empirical findings in this study could be valuable for policy makers in the EU countries in drafting strategies and defining measures and activities aimed at increasing the efficiency and responsiveness of their health systems. Significant attention should be given to the health systems funding, as it is proven that investments in health systems lead to their increased efficiency and resilience. Therefore, it is clear that building comprehensive health systems, with stable public financing and embedded core capacities, will provide the stronger resilience and defense against the future unpredictable pandemics.

Ancklowedgement. The paper presents the results of research supported by the Ministry of Education, Science and Technological Development of the Republic of Serbia (Agreement No. 451-03-9/2021-14/200148)

\section{References}

1. ACEMOGLU D., CHERNOZHUKOV V., WERNING I., WHINSTON M.D., 2020, A multi-risk SIR model with optimally targeted lockdown, National Bureau of Economic Research Working Paper, No. 27102.

2. ALBANESI S., KIM J., 2021, The gendered impact of the COVID-19 recession on the us labor market, National Bureau of Economic Research Working Paper, No. 28505

3. ALON, T.M., DOEPKE M., OLMSTEAD-RUMSEY J., TERTILT M., 2020, The impact of COVID19 on gender equality, National Bureau of Economic Research Working Paper, No. 26947

4. ALVAREZ F.E., ARGENTE D., LIPPI F., 2020, A simple planning problem for COVID-19 lockdown, National Bureau of Economic Research Working Paper, No. 26981.

5. ANAND P., FERRER B., GAO Q., NOGALES R., UNTERHALTER E., 2020, COVID-19 as a capability crisis: Using the capability framework to understand policy challenges, Journal of Human Development and Capabilities, 21(3): 293-299.

6. ASHRAF N., 2020, Stock markets' reaction to COVID-19: cases or fatalities? Research in International Business and Finance, 54, 101249.

7. BAKER S.R., BLOOM N., DAVIS S.J., TERRY S.J., 2020a, COVID-induced economic uncertainty, National Bureau of Economic Research Working Paper, No. 26983.

8. BAKER S.R., FARROKHNIA R.A., MEYER S., PAGEL M., YANNELIS C., 2020b, How does household spending respond to an epidemic? Consumption during the 2020 COVID-19 pandemic, National Bureau of Economic Research Working Paper, No. 26949.

9. BARTIK A.W., BERTRAND M., CULLEN Z.B., GLAESER E.L., LUCA M., STANTON C.T., 2020, How are small businesses adjusting to COVID-19? Early evidence from a survey, National Bureau of Economic Research Working Paper, No. 26989. 
10. BOYCE M.R., ATTAL-JUNCQUA A., LIN J., MCKAY S., KATZ R., 2021, Global Fund contributions to health security in ten countries, 2014-20: Mapping synergies between vertical disease programmes and capacities for preventing, detecting, and responding to public health emergencies, The Lancet Global Health, 9(2): e181-e188.

11. Council of Europe, n.d., Health: Manual for human rights education with young people, https://www.coe. int/en/web/compass/health (20.06.2021).

12. CYLUS J., PAPANICOLAS I., SMITH P.C., 2017a, Using Data Envelopment Analysis to Address the Challenges of Comparing Health System Efficiency, Global Policy, 8(2): 60-68.

13. CYLUS J., PAPANICOLAS I., SMITH P.C., 2017b, How to make sense of health system efficiency comparisons? WHO Regional Office for Europe Policy Brief, No. 27.

14. DYAKOVA M., HAMELMANN C., BELLIS M.A., BESNIER E., GREY C.N.B., ASHTON K. et al., 2017, Investment for health and well-being: a review of the social return on investment from public health policies to support implementing the Sustainable Development Goals by building on Health 2020, Health Evidence Network (HEN) synthesis report 51, WHO Regional Office for Europe, Copenhagen.

15. EICHENBAUM M., REBELO S., TRABANDT M., 2020, The macroeconomics of epidemics, National Bureau of Economic Research Working Paper, No. 26882.

16. Eurostat, 2021, Real GDP growth rate - volume: Percentage change on previous year, https://ec.europa.eu/eurostat/databrowser/view/tec00115/default/ table?lang=en (28.06.2021).

17. FERRANNINI A., BARBIERI E., BIGGERI M., DITOMMASO M., 2021, Industrial policy for sustainable human development in the post-Covid19 era, World Development, 137: 105215.

18. GLOVER A., HEATHCOTE J., KRUEGER D., RIOS-RULL J.V., 2020, Health versus wealth: On the distributional effects of controlling a pandemic, National Bureau of Economic Research Working Paper, No. 27046.

19. GREEN D., LOUALICHE E., 2021, State and local government employment in the COVID-19 crisis, Journal of Public Economics, 193: 104321.

20. JONES C.J., PHILIPPON T., VENKATESWARAN V., 2020, Optimal mitigation policies in a pandemic: Social distancing and working from home, National Bureau of Economic Research Working Paper, No. 26984.

21. JONES K.E., PATEL N.G., LEVY M.A., STOREYGARD A., BALK D., GITTELMAN J., DASZAK P., 2008, Global trends in emerging infectious diseases, Nature, 451: 990-994.

22. John Hopkins University, 2021, Coronavirus Resource Center: Cases and mortality by country, https://coronavirus.jhu.edu/data/mortality (22.06.2021)

23. KANDEL N., CHUNGONG S., OMAAR A., XING J., 2020, Health security capacities in the context of COVID-19 outbreak: An analysis of International Health Regulations annual report data from 182 countries, Lancet, 395(10229): 1047-1053.

24. KAPLAN S., LEFLER J., ZILBERMAN D., 2021, The political economy of COVID-19, Applied Economic Perspectives and Policy, 1-12.
25. LAL A., ERONDU N.A., HEYMANN D.L., GITAHI G., YATES R., 2021, Fragmented health systems in COVID-19: rectifying the misalignment between global health security and universal health coverage, Health Policy, 397(10268): 61-67.

26. MACHMUDDAH Z., UTOMO S.D., SUHARTONO E., ALI S., GHULAM A.W., 2020, Stock market reaction to COVID-19: evidence in customer goods sector with the implication for open innovation, Journal of Open Innovation: Technology, Market, and Complexity, 6(4): 99.

27. MENSI W., SENSOY A., VO X.V., KANG S.H., 2020, Impact of COVID-19 outbreak on asymmetric multifractality of gold and oil prices, Resources Policy, 69, 101829.

28. MORENS D.M., FOLKERS G.K., FAUCI A.S., 2004, The challenge of emerging and re-emerging infectious diseases, Nature, 430: 242-249.

29. MORSE S., MAZET J., WOOLHOUSE M., PARRISH C., CARROLL D., KARESH W., ZAMBRANA-TORRELIO C., LIPKIN I., DASZAK P., 2012, Prediction and prevention of the next pandemic zoonosis, Lancet, 380: 1956-1965.

30. Nuclear Threat Initiative, Johns Hopkins Center for Health Security, 2019, Global Health Security Index Report, https://www.ghsindex.org/wp-content/uploa ds/2020/04/2019-Global-Health-Security-Index.pdf.

31. OECD, 2020, Strengthening health systems during a pandemic: The role of development finance, OECD Policy Responses to Coronavirus (COVID-19).

32. OECD, European Union, 2020, Health at a Glance: Europe 2020: State of Health in the EU Cycle, OECD Publishing, Paris.

33. OZKAN O., 2021, Impact of COVID-19 on stock market efficiency: Evidence from developed countries, Research in International Business and Finance, 58: 101445.

34. RAVI S.J., WARMBROD K.L., MULLEN L., MEYER D., CAMERON E. et al., 2020, The value proposition of the Global Health Security Index, $B M J$ Global Health, 5: e003648.

35. REINHARDT U.E., HUSSEY P.S., ANDERSON G., 2002, Cross-National Comparisons of Health Systems Using OECD Data, 1999, Health Affairs, 21(3): 169181.

36. STOJANOVIĆ-JOVANOVIĆ S., KRSTIĆ B., MARKOVIĆ M., 2020, International Business and Management in Pandemic-Related Conditions, Economics of Sustainable Development, 4(2): 25-36.

37. STREET A., HAKKINEN U., 2009, Health system productivity and efficiency, Performance measurement for health system improvement: Experiences, challenges and prospects, eds. Smith P.C. et al., Cambridge University Press, Cambridge.

38. United Nations, 2020, Human Development Index Ranking, http://hdr.undp.org/en/data (23.06.2021).

39. WEBSTER R.G., 1997, Predictions for future human influenza pandemic, Journal of infectious disease, 176: S14-S19.

40. World Bank, 2020, The Economic and Social Impact of COVID-19: Health systems, Western Balkans Regular Economic Report, 17.

41. World Bank, 2021, Current health expenditure per capita, PPP (current international \$), https://data.world bank.org/indicator/SH.XPD.CHEX.PP.CD.

42. ZHANG D., HU M., JI Q., 2020, Financial markets under the global pandemic of COVID-19, Finance Research Letters, 36: 101528. 